\title{
Testing of a 50-kW Wind-Diesel Hybrid System at the \\ National Wind Technology Center
}

David A. Corbus, H. James Green April Allderdice, Karen Rand Jerry Bianchi National Renewable Energy Laboratory

Ed Linton New World Village Power

Prepared for AWEA Windpower '96 Denver, Colorado June 23-27, 1996

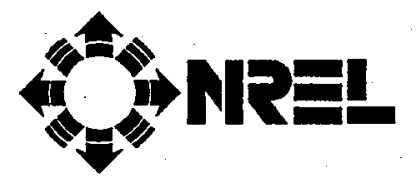

National Renewable Energy Laboratory 1617 Cole Boulevard Golden, Colorado 80401-3393 A national laboratory of the U.S. Department of Energy Managed by Midwest Research Institute for the U.S. Department of Energy under contract No. DE-AC36-83CH10093

Prepared under Task No. WE617310 July 1996 


\begin{abstract}
NOTICE
This report was prepared as an account of work sponsored by an agency of the United States government. Neither the United States govemment nor any agency thereof, nor any of their employees, makes any warranty, express or implied, or assumes any legal liability or responsibility for the accuracy, completeness, or usefulness of any information, apparatus, product, or process disclosed, or represents that its use would not infringe privately owned rights. Reference herein to any specific commercial product, process, or service by trade name, trademark, manufacturer, or otherwise does not necessarily constitute or imply its endorsement, recommendation, or favoring by the United States govemment or any agency thereof. The views and opinions of authors expressed herein do not necessarily state or reflect those of the United States govemment or any agency thereof.
\end{abstract}

Available to DOE and DOE contractors from:

Office of Scientific and Technical Information (OSTI)

P.O. Box 62

Oak Ridge, TN 37831

Prices available by calling (423) $576-8401$

Available to the public from:

National Technical Information Service (NTIS)

U.S. Department of Commerce

5285 Port Royal Road

Springfield, VA 22161

(703) $487-4650$ 


\title{
TESTING OF A 50-kW WIND-DIESEL HYBRID SYSTEM AT THE NATIONAL WIND TECHNOLOGY CENTER $\mathrm{f}$
}

\author{
David A. Corbus \\ Jim Green, April Allderdice, Karen Rand \& Jerry Bianchi \\ National Renewable Energy Laboratory \\ 1617 Cole Blvd. \\ Golden, CO 80401-3393 \\ United States of America
Ed Linton
New World Village Power
One North Wind Road
PO BOX 999
Waitsfield, VT 05673
United States of America

\section{INTRODUCTION}

In remote off-grid villages and communities, a reliable power source is important in improving the local quality of life. Villages often use a diesel generator for their power, but fuel can be expensive and maintenance burdensome. Including a wind turbine in a diesel system can reduce fuel consumption and lower maintenance, thereby reducing energy costs. However, integrating the various components of a wind-diesel system, including the wind turbine, power conversion system, and battery storage (if applicable), is a challenging task.

To further the development of commercial hybrid power systems, the National Renewable Energy Laboratory (NREL), in collaboration with the New World Village Power Corporation (NWVP), tested a NWVP 50-kW wind-diesel hybrid system connected to a 15/50 Atlantic Orient Corporation (AOC) wind turbine. Testing was conducted from October 1995 through March 1996 at the National Wind Technology Center (NWTC). A main objective of the testing was to better understand the application of wind turbines to weak grids typical of small villages. Performance results contained in this paper include component characterization, such as power conversion losses for the rotary converter system and battery round trip efficiencies. In addition, system operation over the test period is discussed with special attention given to dynamic issues. Finally, future plans for continued testing and research are discussed.

\section{System Description}

The hybrid power system includes a synchronous generator that provides 3-phase power to the load. This is coupled to a DC machine on one side and through a clutch to a diesel engine on the other side. AC current is converted to DC current when the DC machine runs as a generator, thereby allowing the batteries to be charged. When the clutch is disengaged on the diesel, the batteries may power the DC machine and the DC machine can supply torque to the AC generator. Frequency on the system may be controlled either by the diesel governor (diesel on) or the DC machine and programmable logic controller (PLC) (diesel off). An AOC 15/50 wind turbine is connected in parallel to the load to reduce diesel fuel consumption, with excess wind power charging the batteries or being dissipated by a resistive dump load. Table 1 lists the major components of the system [New World Village Power, 1994], and Figure 1 shows a system schematic with the location of the sensors used in the data acquisition system. 
TABLE 1. System Components

\begin{tabular}{|c|c|c|}
\hline \multicolumn{2}{|c|}{$\begin{array}{ll}\text { Rotary Converter } \\
\end{array}$} & Diesel Engine \\
\hline AC Synchronous Machine & DC Machine & Northern Lights Lugger \\
\hline $480 \mathrm{~V}, 3$ phase, $60 \mathrm{~Hz}$ & $\begin{array}{l}240 \mathrm{~V} \text { armature (300 V generating) rated } \\
\text { for } 309 \mathrm{~A} @ 200 \mathrm{~V}\end{array}$ & $75 \mathrm{Hp}, 1800 \mathrm{RPM}$ \\
\hline $\begin{array}{l}50 \mathrm{kWe} \text { and } 62 \mathrm{KVA} \text { continuous } \\
75 \mathrm{kWe} \text { peak ( } 30 \mathrm{sec})\end{array}$ & $\begin{array}{l}150 \mathrm{~V} \text { field, } 3 \text { A nominal, } 6 \text { A maximum } \\
55 \mathrm{~kW}, 4 \text { Pole Shunt Wound } \\
1800 \text { RPM }\end{array}$ & $\begin{array}{l}4 \text { cylinder, turbocharged } \\
\text { Radiator cooled }\end{array}$ \\
\hline Dump Load & Controller & Battery Bank \\
\hline $480 \mathrm{~V}, 3$ phase & Omron PLC Controller & $\begin{array}{l}\text { C\&D HD700, valve-regulated, } \\
\text { absorbent glass mat, lead-calcium } \\
\text { batteries }\end{array}$ \\
\hline $75 \mathrm{~kW}$ continuous & & $\begin{array}{l}114 \text { cells, } 700 \mathrm{AHr} \text { (nominal } 5 \mathrm{Hr} \text { rating } \\
\text { to } 1.88 \mathrm{~V} \text { per cell) }\end{array}$ \\
\hline Resistive Load Bank & $\begin{array}{l}\text { New World Village Power Remote } \\
\text { Operator Interface }\end{array}$ & \\
\hline
\end{tabular}

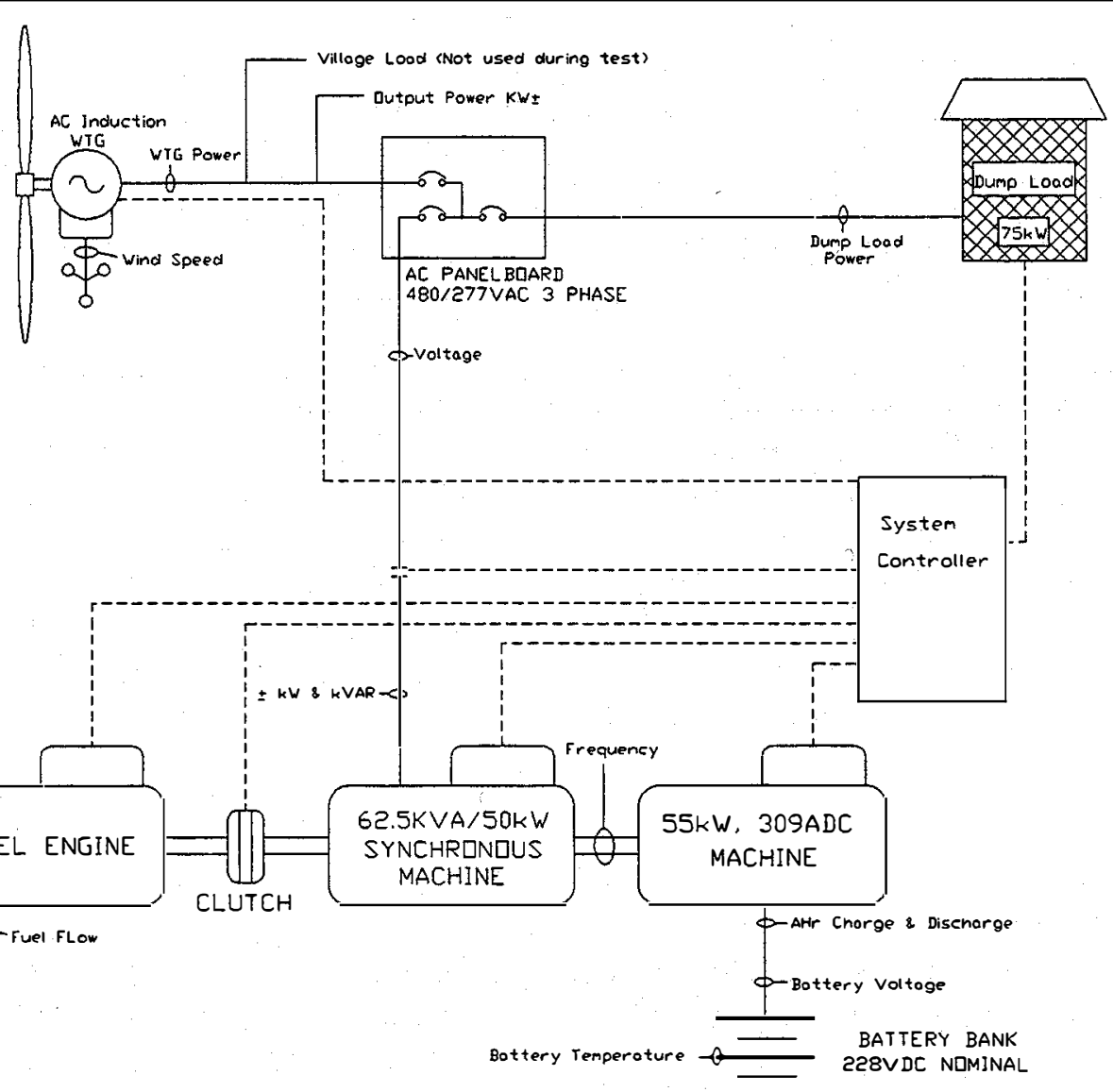

FIGURE 1. System Schematic 


\section{COMPONENT CHARACTERIZATION TESTS}

The initial hybrid system testing focused on component characterization. We calculated component efficiencies of the rotary converter and battery bank for different operating states, and we measured wind turbine power output. Evaluation of fuel efficiency (i.e., liters/kWh) is pending until installation of a fuel flow meter.

AOC 15/50 wind turbine. The AOC $15 / 50$ is a downwind, stall regulated, 15 meter rotor-diameter turbine that is rated at $50 \mathrm{~kW}$ for a $11 \mathrm{~meter} / \mathrm{sec}$ wind speed. Maximum continuous power output from the turbine, based on the published power curve, is $65 \mathrm{~kW}$ [Atlantic Orient Corporation, 1994]. Test data for the $15 / 50$ turbine connected to the utility grid showed maximum peak power of $83 \mathrm{~kW}$ for a two-second average wind speed, as shown in Figure 2. Figure 2 also shows minimum power reaching $-25 \mathrm{~kW}$. (Because of the air density variation due to the altitude at the NWTC, the average power data shown in Figure 2 differ from the published power curve.)

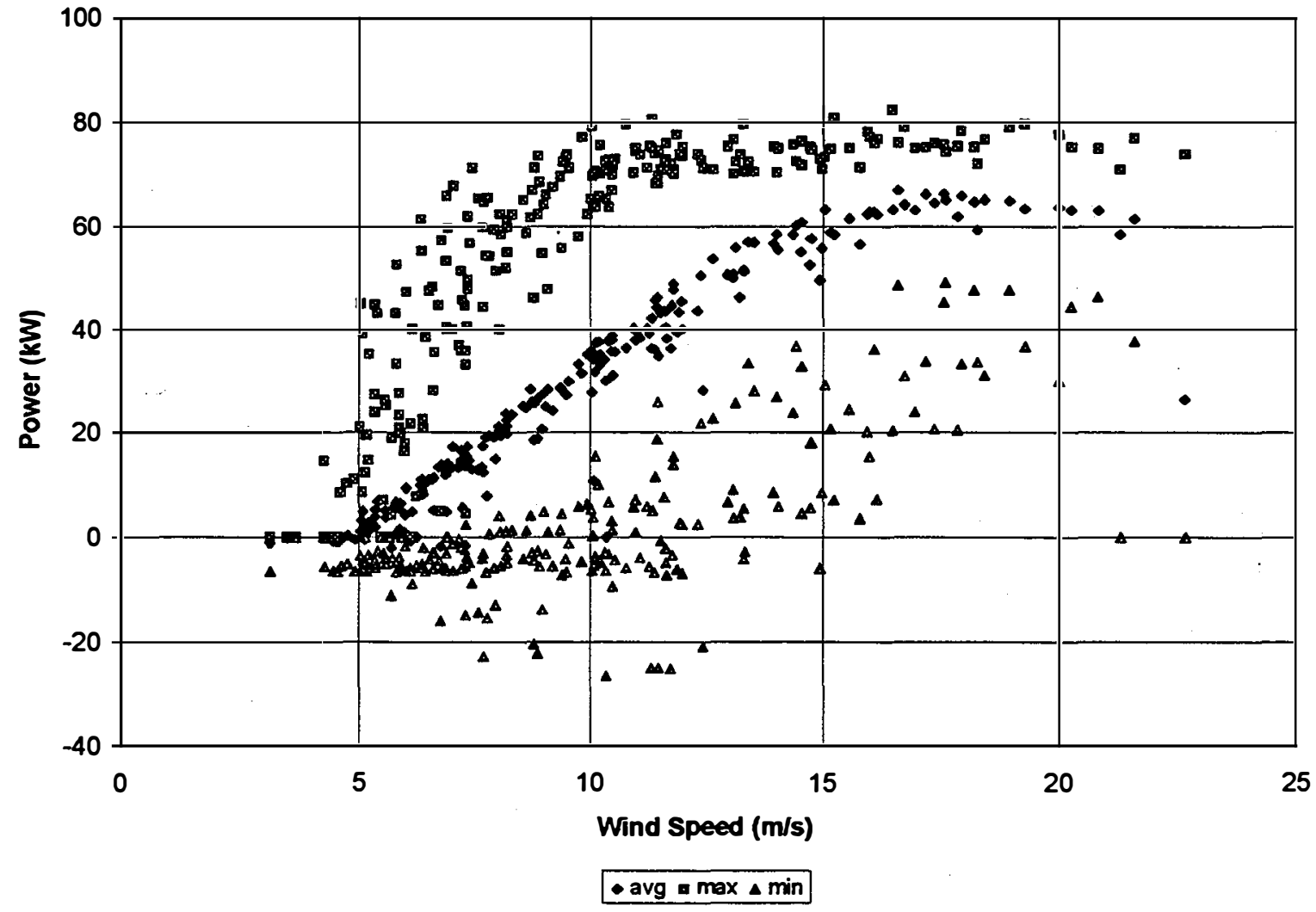

FIGURE 2. AOC Power Output (2 sec. avg.)

Rotary converter efficiency. To evaluate the rotary converter efficiency, we measured power input to and from the AC synchronous generator, power to and from the battery bank, battery bank voltage, and diesel run time (see Figure 1 for sensor locations). The system dump load was used as a power sink for power 
out of the AC synchronous generator. Data was taken every tenth of a second and recorded as ten-minute averages.

For energy flowing from the battery bank to the AC bus, a data set of 104 time steps with zero diesel and zero wind turbine run time was used. The graph of power out of the $\mathrm{AC}$ machine versus power from the batteries is shown in Figure 3. The performance of the rotary converter was found to obey the relationship:

$$
y=1.135 x+2.98
$$

For energy flowing from the AC bus to the battery bank, a concatenated data set of 360 time steps with the wind turbine as the source of power was used (i.e., zero diesel run time and zero battery discharge). The graph of power to the battery bank versus power into the $\mathrm{AC}$ machine is shown in Figure 4. The performance of the rotary converter was found to be:

$$
y=1.135 x+2.85
$$

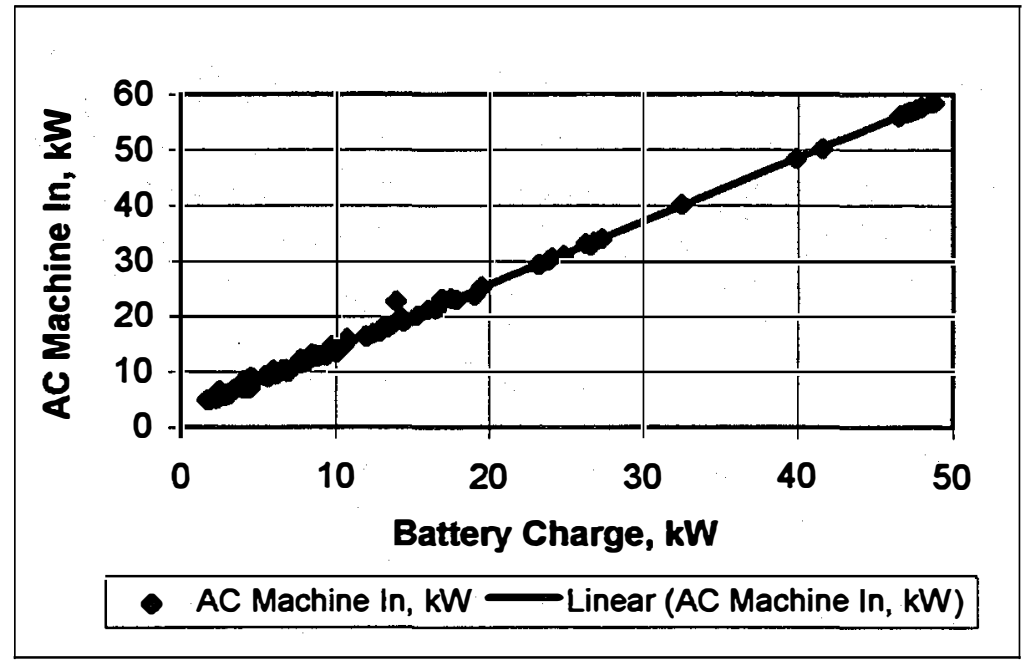

In these equations, $y$ is the power input to the rotary converter in $\mathrm{kW}$ and $\mathrm{x}$ is the power output from the rotary converter in $\mathrm{kW}$. The y-intercept ( 2.85 and $2.98 \mathrm{~kW}$ ) represents the fixed losses for the system, or the standing losses, and are constant because the rotary converter operates at a fixed speed. (These losses are slightly different depending on the direction of power flow, i.e., DC-AC or AC-DC, because of the difference in conversion efficiency of the $\mathrm{AC}$ and DC machines.) Electrical losses scale with the amount of power through the rotary converter and may be calculated from the slope of the curve in Figures FIGURE 3. Converter Performance AC to DC 3 and 4; they are about equal. A graph of overall rotary converter efficiency as a function of power is given in Figure 5.

Battery charging efficiency. The hybrid system uses valve regulated lead acid (VRLA) batteries. The battery efficiency depends on temperature, depth of discharge, length of tapering charge, rate of charge and discharge, age and condition of batteries. We characterized batteries for the actual operating conditions of the system, and this included analysis of the battery efficiency under both a constant load and a preprogrammed diumal "village" load. 


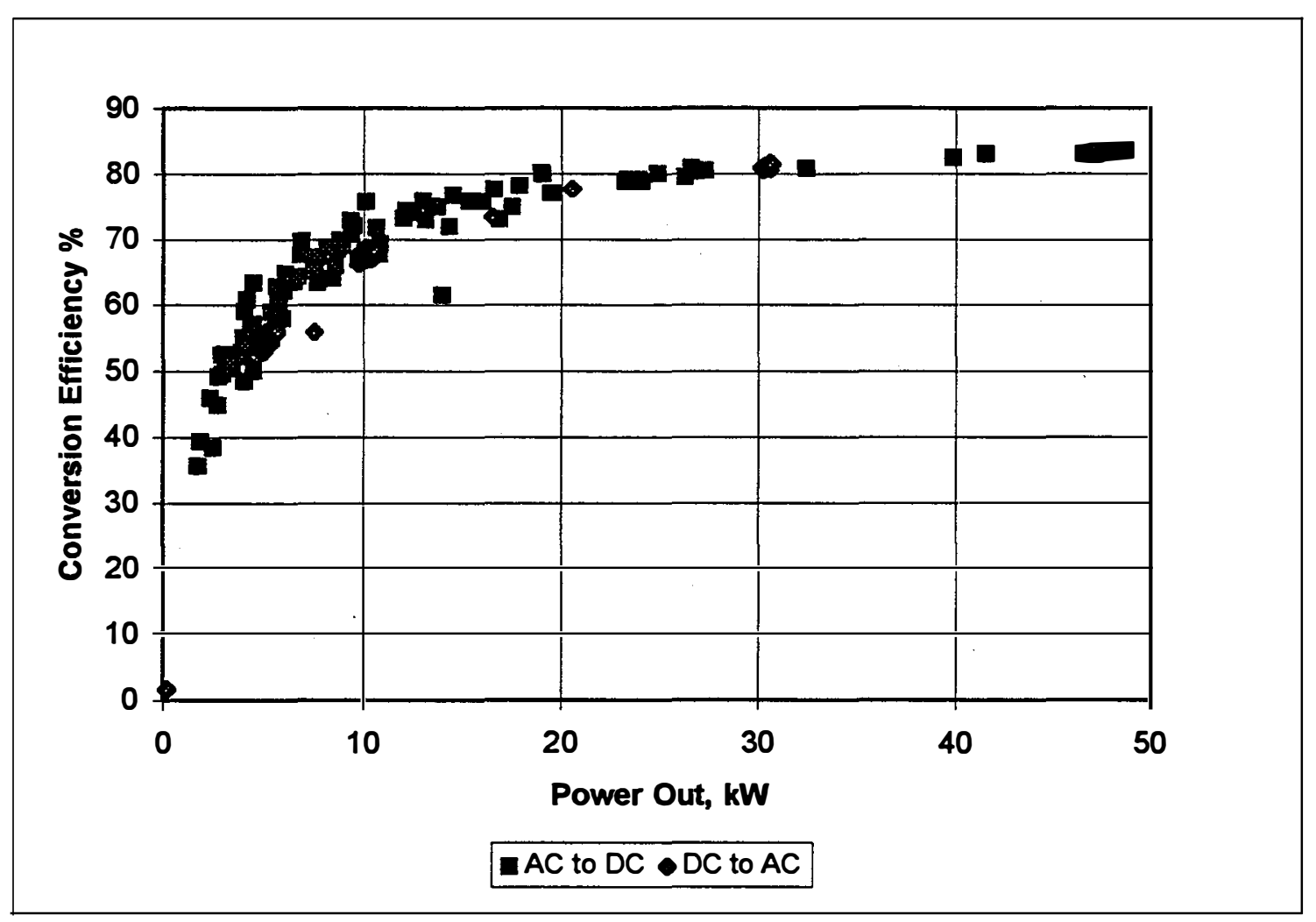

FIGURE 5. Rotary Converter Efficiency

To characterize the battery efficiency for a constant load, the battery bank was charged by the diesel generator at a constant current and then discharged for a constant load for four battery charge/discharge cycles. The batteries performed at a $90 \%$ watt-hour efficiency. The temperature of the battery bank measured between $25^{\circ}$ and $35^{\circ} \mathrm{C}$. When compensated for high temperature, the watt-hour battery efficiency was about $80 \%$, which is within the expected $65 \%-80 \%$ range for VRLA batteries [Berndt, 1993]. A graph of battery voltage, current, and temperature during this test is shown in Figure 6.

Battery performance was also characterized for a simulated village load profile, without using the wind turbine. The batteries performed at an $88 \%$ watt-hour efficiency. The temperature of the battery bank measured between $30^{\circ}$ and $40^{\circ} \mathrm{C}$. When compensated for high temperature, the battery efficiency is also about $80 \%$. A graph of battery voltage, current, and temperature during this test is shown in Figure 7. In both cases, the transducers monitored only the battery bank, so rotary converter losses are not included in these efficiencies.

Overall rotary converter/battery system efficiency. For energy from the wind turbine and passing through the battery bank before meeting a village diumal load, the system has a round-trip overall efficiency of $62 \%$ at full load: $83 * .90 * .83=.62$ (i.e., $83 \%$ conversion efficiency one way and battery efficiency of $90 \%$ ).

\section{EXTENDED OPERATION OF SYSTEM}

System Tests. We conducted system testing from December 1995 through March 1996. Because of competing uses for the turbine and dynamic issues associated with operation of the system, testing of the system was intermittent. The majority of the testing was conducted using a typical village load profile that 
Battery Round Trip Efficiency over 4 cycles Load $=20 \mathrm{~kW}$

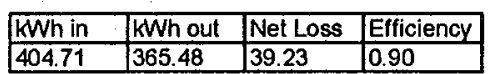

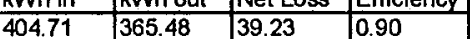

Voltage

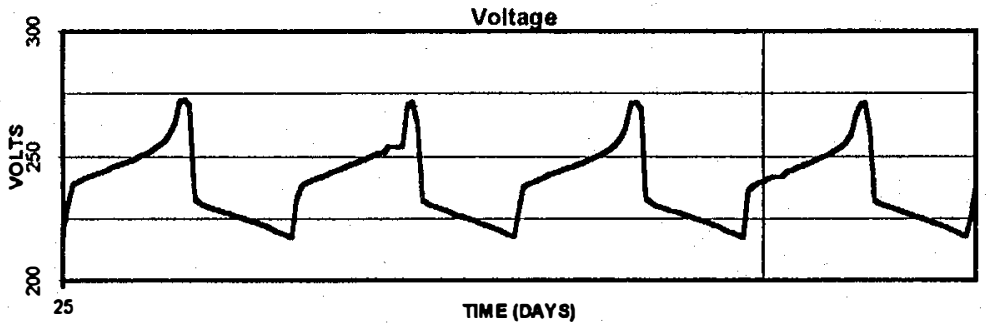

Current

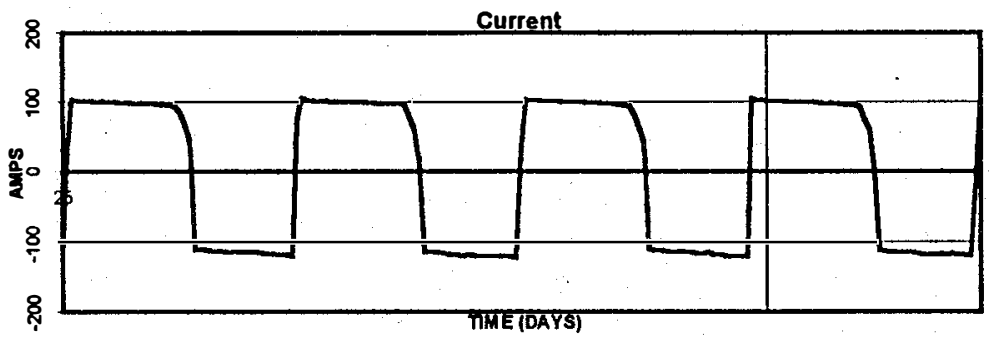

Temperature

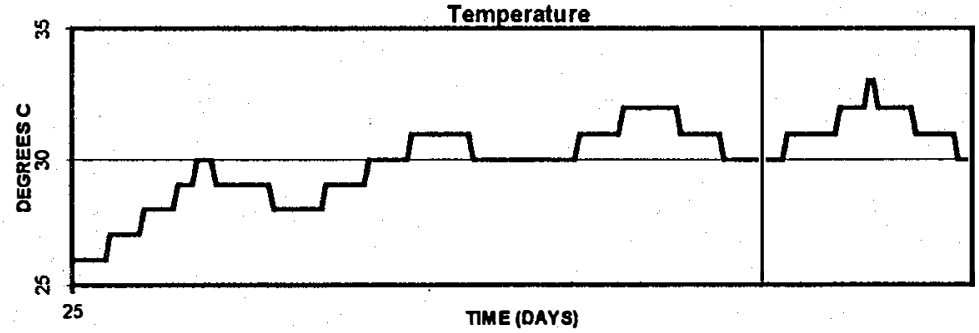

FIGURE 6. Constant Load Condition
Battery Round Trip Efficiency over 5 cycles

Village Diurnal Load

\begin{tabular}{|l|l|l|l|}
\hline KWh in & KWh out & Net Loss & Efficiency \\
\hline
\end{tabular}

\begin{tabular}{l|r|r|r}
\hline 636.71 & 559.69 & 77.01 & 0.88 \\
\hline
\end{tabular}

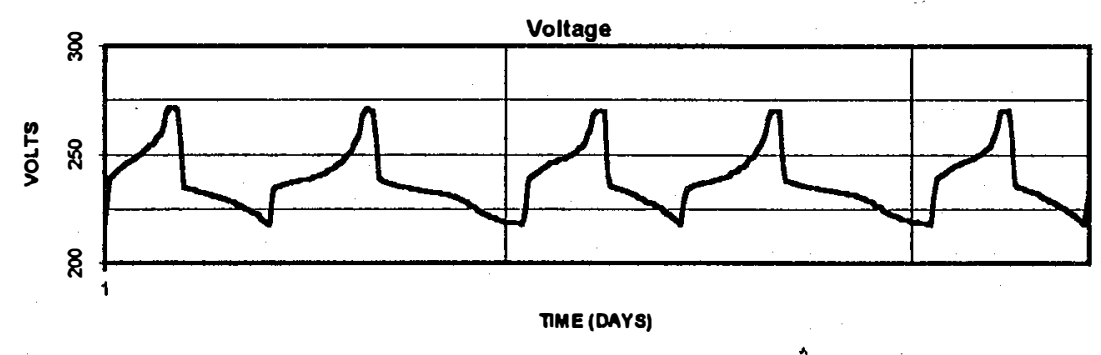

Current
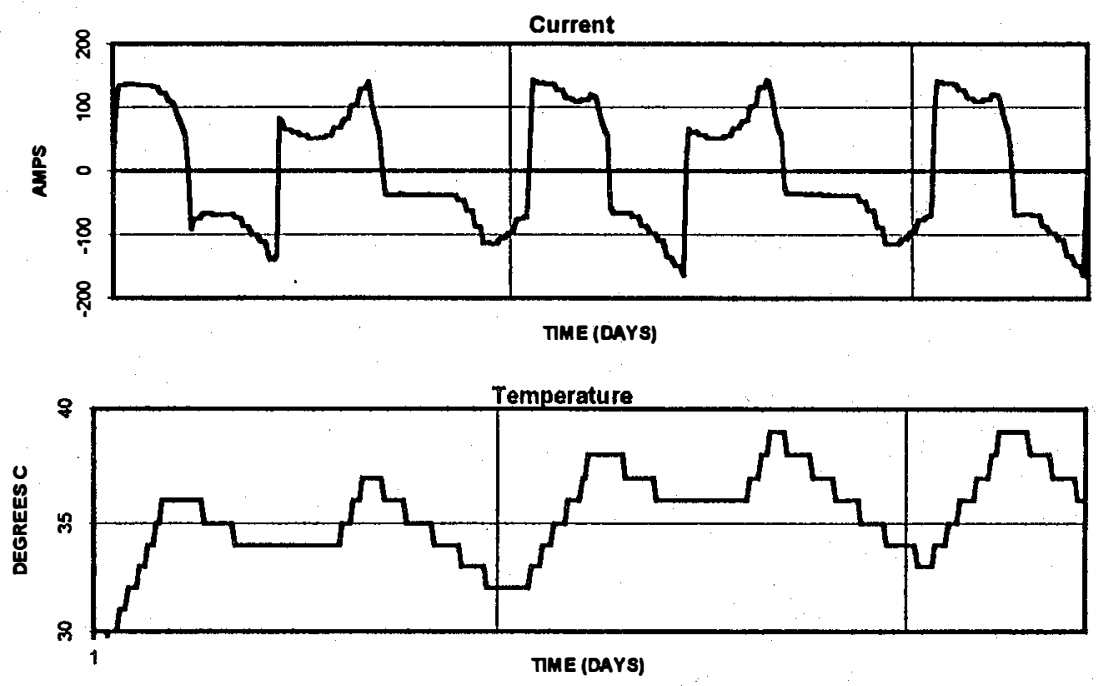

FIGURE 7. Diurnal Load Condition 
is shown in Figure 8. The resistive dump load was used to simulate the village load for system testing.

Although the dump load comprises resistive elements, the power factor on the system was usually low because of harmonic distortion created by the silicon controlled rectifier (SCR) switches in the phase-controlled dump load controller.

The data acquisition system recorded operating parameters in ten-minute averages. Based on the ten-minute

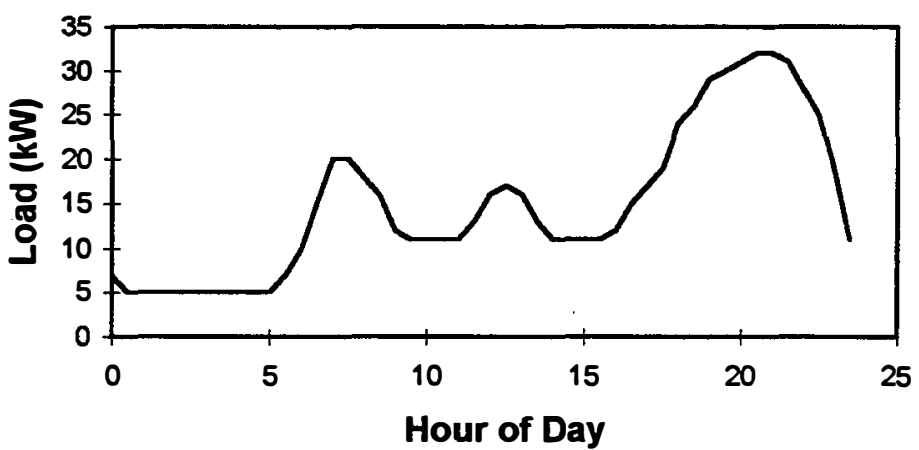

FIGURE 8. Diurnal Load Profile averages, weekly summaries for the system were produced that show on-line time, diesel run time, total wind turbine energy, total load, dumped energy, diesel starts, and battery cycles. In addition, operating parameters such as wind power, load setting, dumped power, and battery state-of-charge were plotted. An example on one of these plots is shown for 7 days in Figure 9. Note the dumped power is high when the batteries are fully charged and the wind speed is high, and that the system is off when the load power is zero.

Rotary converter. In March 1996, large vibrations were noticed on the AC synchronous generator, so the system was shut down and disassembled. Inspection showed severe wear on the spline connection from the AC generator shaft to the diesel clutch. The AC generator was converted from a single bearing to a double bearing system to reduce transverse loads on the clutch-to-spline connection. The system was up and running again in June, but operating data and analysis results for this paper are included only through March.

Batteries. One of the problems encountered with operation of the batteries was temperature control. Temperature control of VRLA batteries is important, because if cells are allowed to operate at too high a temperature, their lifetime may be shortened as a result of loss of electrolyte. VRLA batteries are "maintenance free," hence their electrolyte cannot be replaced. Although the exact correlation between cell lifetime and operating temperature is poorly understood, it is always prudent to operate batteries near their rated temperature of $25^{\circ} \mathrm{C}$.

One of the advantages of VRLA batteries is that they can be stacked on top of one another, thereby reducing the space required to house them. However, the stacked battery cells are harder to keep cool; hence, we will install an air conditioner to keep batteries cool during testing when ambient temperatures are high.

An alternative to VRLA batteries is flooded lead-acid batteries. For systems of this type, especially those installed in warm climates, we recommend that flooded lead-acid cells be considered because of their tolerance of higher temperatures and their reduced costs. Disadvantages of flooded lead-acid batteries are their larger space requirements and need for maintenance. The degree of maintenance (e.g., watering of batteries) varies for different types of flooded lead-acid batteries.

Dynamic issues. Three dynamic issues arose during system testing: negative power from the wind turbine, larger-than-anticipated power transients from the wind turbine, and high battery voltage excursions. The 
first two issues are primarily a result of integrating the $A O C$ $15 / 50$ turbine with the NWVP system, while the last issue is more closely related to system control of the rotary converter system.

The first dynamic issue, negative power from the wind turbine, occurred during extremely turbulent, high wind conditions. As shown in Figure 2 , power output from the $A O C$ $15 / 50$ wind turbine is negative at times. In fact, negative power excursions as low as $-70 \mathrm{~kW}$ were observed on the system in very high turbulent wind conditions. (During this testing we did not identify the cause of these extreme excursions; however, we will investigate this in subsequent testing). During the negative power surges, the rotary converter system supplies power to the turbine to motor it, but in many cases the current was over the DC machine rating, so the PLC would shut down the DC part of the system. (During a DC fault, the diesel generator takes over control of the system so that the load continues to be met, which is an important feature of the hybrid system.)

We changed the PLC to disconnect the turbine whenever the power went below $-10 \mathrm{~kW}$. Although this resulted in significant turbine downtime during periods when the turbulent conditions existed, these conditions were infrequent, so overall turbine downtime was not excessive. (Because the testing was intermittent, total downtime from this condition at this site is hard to estimate, but might be on the order of 10 days during the peak four months of wind.)

There are two approaches to mitigate this problem. A high speed tachometer could be added to the turbine to detect transient underspeeding of the turbine and shut it down during negative power events before the hybrid system grid tried to motor the turbine. (The existing turbine tachometer does not have enough resolution to detect very short-term changes in turbine speed and hence could not be used.) The approach would result in a situation similar to the existing solution of cutting the wind turbine out at $-10 \mathrm{~kW}$; both could put excessive wear on the turbine breaking system. The second approach is to install an 
asynchronous controller on the turbine so that it could go below synchronous speed momentarily and have the power regulated on the grid. These two approaches will be considered in follow up testing.

The second dynamic issue, higher-than-anticipated power output from the wind turbine, was a problem for system testing because the existing $75 \mathrm{~kW}$ of dump load capacity could not absorb the peak $83 \mathrm{~kW}$ of power from the turbine during extremely high winds. As a result, the turbine would overspead and shut itself down, although the hybrid power system would continue to operate. The turbine would go into a normal 7-minute cool down before restarting itself and reconnecting to the system. This condition would not be a problem for actual installations in most villages, because a village would have a continuous base load of about $10 \mathrm{~kW}$. However, the higher-than-anticipated turbine output did require the addition of extra test load capacity to the dump load. For village systems, we recommend sizing the dump load for the maximum short-term turbine power output minus the minimum expected base load.

High battery voltage was the third dynamic issue we identified. When the wind turbine is charging the batteries, current is supplied to the batteries until a high voltage set point on the batteries is reached, then the current is supplied to the dump load. However, power spikes from the turbine resulted in transient high battery voltage excursions because the PLC was not able to shift power from the batteries to the dump load fast enough. Although changes to the dump load controller gain were made, further changes are required to mitigate this problem. This could include changing the size of the dump load increments or implementing PID dump load control.

System Startup. In the beginning of the testing the hybrid system grid could not handle a "hard start," (i.e., the hybrid system could not motor the turbine up to synchronous speed), because the in-rush currents to the turbine were too high for the hybrid system grid. Hence, the PLC was changed to allow the turbine to coast up to synchronous speed before connecting to the hybrid system grid.

Dump load. Harmonic noise (20\%-25\% total harmonic distortion ) was created by the phase controlled dump load, and this set off a voltage alarm on the turbine and caused other problems. For future systems, changing to a binary step, zero crossing solid-state-relay dump load should eliminate this problem.

General maintenance. Routine diesel maintenance was required for the system (e.g., changing oil and oil filters). In addition, water was frozen in the breather for the system which resulted in a broken seal on the turbo that had to be replaced. Aside from the major generator retrofit to the double bearing system, equipment maintenance on the NWVP system was low.

\section{FUTURE WORK}

We plan to make additional changes to the PLC software to mitigate the high battery voltage events, and to further test the system response to step changes in load, loss of load, and power quality for various events, such as severe phase imbalance and induction motor starts. Short-term power quality measurements will also be performed to help further understand dynamic issues, and we will record fuel flow measurements and estimate fuel efficiency (i.e., liters/kWh) for the system. Finally, the negative power from the AOC $15 / 50$ will be investigated to determine why it is happening and under what type of conditions, and various approaches will be implemented to mitigate the effect that negative power has on the hybrid system grid.

\section{CONCLUSIONS}

Testing of the system has demonstrated the challenges of integrating specific wind turbine characteristics into a small, weak grid (i.e., a grid typical of a small village), as is demonstrated by the NWVP 50-kW 
system. In our testing, we had to make changes to the NWVP system's controller so that the hybrid system could handle the AOC 15/50's negative power events and so that high battery voltage events caused by transient peak power from the turbine could be minimized. For hybrid systems of this type, a good PLC code is required for system control, and changes to this software will be needed depending on the specific turbine connected to the system.

\section{REFERENCES}

New World Village Power. 1994. "Renewable Energy Modules for Village Electrification." Waitsfield, Vermont: The New World Power Corporation.

Atlantic Orient Wind Systems. 1994. "Producing Tomorrow's Wind Turbines Today. "Waitsfield, Vermont: Atlantic Orient Wind Systems Inc.

Berndt, D. 1993. Maintenance-Free Batteries. Somerset, England: John Wiley and Sons. 